\title{
Jundi-Shapur, bimaristans, and the rise of academic medical centres
}

\author{
Andrew C Miller
}

J R Soc Med 2006;99:615-617

\section{IMPORTANCE}

The academic medical centre plays a critical role in modern society and serves as the heart of our profession. Its origins have been inaccurately described by many western medical history texts as occurring in Europe during the middle ages or early renaissance period. It is important for us to know how our profession evolved from the shamanistic practices of yore to the powerful evidence-based medicine industry of today. This article explores how ancient near- and middle-easterners combined the medical traditions of Persians, Greeks, Indians, Zoroastrians, Jews and Nestorians into an innovative product that would give rise to academic medical centres, medical records, physician licensure, and numerous other medical and scientific advances. Furthermore, the route by which Europe inherited this knowledge is explored. As a profession that seeks truth and knowledge in the world, we must acknowledge the influence of non-westerners in the development of modern academic medicine.

\section{INTRODUCTION}

With the exception of the hospital at Jundi-Shapur, hospitals as we now know them probably were not present prior to $400 \mathrm{AD}$. Prior to this era, the sanatoria and travel lodges of antiquity were either temples or temple annexes, where the infirm were minded by attendant priests. ${ }^{1}$ Most of the therapy in these sanatoria consisted of prayers and sacrifices to gods such as Asclepius or Imhotep, and cures were attributed to divine intervention. ${ }^{1,2}$ The treatments in Greek 'Asclepia' and Byzantine 'Nosocomia' were rendered as a mixture of shamanistic practices and purgative drugs. ${ }^{2}$ In contrast, treatments at the Jundi-Shapur hospital and later Islamic bimaristans were based on scientific analysis, in true Hippocratic tradition. ${ }^{1}$ 'Bimaristan' is a word of Persian origin meaning 'location of disease.' The bimaristan at Jundi-Shapur served as a stepping stone for future advancements in medical care, hospital organization and structure, medical records, physician and pharmacist licensure, and medical education. Under the patronage of

Dr Andrew C Miller, Departments of Internal Medicine and Emergency Medicine. State University of New York Downstate Medical Centre and Kings County Hospital Centre. Brooklyn, New York, USA.

E-mail: andrewcmiller@optonline.net the Islamic empire, near- and middle-easterners both preserved ancient knowledge and flourished to blossom into scientific innovators with originality and productivity in their own right. Following the destruction of Baghdad by the Mongols in $1258 \mathrm{AD}$, and Spain's re-conquest in the late 1400s, many Arab and Persian medical contributions were lost to the west until recently. ${ }^{3}$ This is particularly true in the case of hospitals and medical education. The bimaristans of yore were similar in philosophy, structure and function to contemporary academic medical centres, and served as a model for those to follow in Europe.

\section{JUNDI-SHAPUR AND THE TRANSMISSION OF KNOWLEDGE FROM GREEK TO ARABIC}

Jundi-Shapur, meaning 'Beautiful Garden', was a city in Khuzistan founded by the Sasnid Emperor Shapur I (241272 AD). ${ }^{1,4}$ Located in south-western Persia, the site is now marked by the ruins of Shahbad near the city of Ahwaz. It was first established to settle Greek prisoners. With time, it became a refuge and melting pot for intellectuals from various regions. Many Syrians took refuge there when Antioch was captured by Shapur I. ${ }^{1,4}$ The Nestorians were granted refuge under the patronage of Shapur II when the School of Edessa was purged by the Byzantines in 457 and later shut down by Emperor Zeno in 489 AD. 1,5 The closing of the Athenian school by the Byzantine Emperor Justinian (529 AD) also drove many leaned Greek physicians to Jundi-Shapur. ${ }^{1,4}$ Subsequently, a university, medical school and hospital was established by Khusraw (Chosroes) Anushirawan in about 555 AD. ${ }^{3}$ It was here that a uniquely tolerant and peaceful meeting point for the study of the philosophical and medical traditions of Persians, Greeks, Indians, Zoroastrians, Jews and Nestorians developed, serving as the foundation for the tremendous medical advancements set to occur under Muslim rule. In fact Harith bin Kalada, the Prophet Mohammed's physician, trained at Jundi-Shapur. ${ }^{6}$

During the Abbasid Caliphate, Caliph Abu Jaifar AlMansur relocated the capital from Damascus to Baghdad in 762 AD. When he fell ill in 765 AD, he summoned Jirjis ibn Bukhtyishu, the Nestorian Chief of the Jundi-Shapur Hospital, to cure him. ${ }^{3}$ After successfully treating the Caliph, he was appointed to the court. His son, Jibrail ibn 
Bukhtyishu, was later invited to Baghdad during the reign of Caliph Harun Al-Rashid to build the first bimaristan in Baghdad., 7 By the latter half of the second century $\mathrm{AH}$ (after Hijra), the fame of Baghdad had risen not only as the political, intellectual and scientific leader of the caliphate. Many bimaristans were established and tremendous intellectual activity was recorded, culminating in the 'Golden era of Islamic Medicine.'

\section{BIMARISTANS UNDER THE ISLAMIC EMPIRE}

The bimaristans were of two types; mobile and fixed. ${ }^{8}$ The mobile bimaristan dates back to the time of the Prophet Muhammad. During the Ghazwah Khandaq (the Battle of the Ditch), a separate tent was erected for the wounded. Over time, Caliphs and rulers developed and extended these 'MASH' units into true travelling dispensaries with doctors and pharmacists. ${ }^{9}$ These bimaristans were transported upon beasts of burden. ${ }^{8}$ The physicians in the mobile clinics were of the same standing as those in fixed hospitals, and the field hospitals were well equipped with medicaments, instruments, tents, and a staff of doctors, nurses and orderlies. ${ }^{8}$ These mobile bimaristans allowed state services to reach the disabled, the disadvantaged, and those in remote areas. ${ }^{9}$ By the reign of the Seljuq Turkish Sultan Muhammad Saljuqi, the mobile bimaristan had become so extensive that its equipment needed forty camels to transport it.

There is some controversy as to the events surrounding the construction of the first permanent Islamic bimaristan. Many credit the Ummayad Caliph Al-Walid bin Abdel Malik with building the first permanent bimaristan in Damascus in 707 AD (88 AH).6,9 This bimaristan treated chronically ill patients such as lepers and blind people. However, some consider it no more than a lepersoria, as it permitted the quarantine of patients with leprosy from others. There were salaried physicians on staff at all times, and the leprosy patients were treated gratis and granted a monetary stipend upon discharge.

The first agreed permanent Muslim-patroned bimaristan was built during the reign of Caliph Harun Al-Rashid (786809 AD [170-193 AH]). ${ }^{1}$ As described earlier, the Caliph invited the son of the chief physician, Jibrail Bukhtyishu, to come to Baghdad and head the new bimaristan. It rapidly achieved fame, resulting in the construction of others.

Those chosen to oversee the construction of a new bimaristan were diligent to choose the best locations with regard to health conditions. They preferred to erect bimaristans atop hills or along rivers. For example, the Al-Adudi Hospital was built near Baghdad's Dejlah River in 981 AD. The river flowed through its courtyard and halls and returned to pour into the Dejlah. When Caliph Harun to build Baghdad General Hospital, Al-Razi had pieces of meat hung in various quarters of the city, observed their putrefaction, and advised the Caliph to site the bimaristan where the putrefaction was the slowest and the least. ${ }^{10}$

The Al-Mansuri Hospital was constructed in Cairo in $1284 \mathrm{AD}$ at the behest of the Egyptian ruler Al-Mansur Qalawun, and served as a prototype for subsequent bimaristans. ${ }^{7,11}$ The Al-Mansuri bimaristan was one of the largest and most elaborate hospitals ever built. It had a total capacity of 8000 beds, and the annual income from endowments alone was one million dirhams. It freely served all citizens without regard for their colour, religion, sex, age or social status. ${ }^{11}$ There was no limit to the time a patient could be treated as an inpatient, thus the patient could stay until he was fully recovered. Patients who were cured of their maladies but still too weak for discharge were transferred to the convalescent ward until they were healthy enough to leave.

Men and women occupied separate but equally equipped wards and were attended by nurses and orderlies of the same sex. ${ }^{9}, 12,13$ There were separate wards for medicine, surgery, fever, wounds, mania and eye diseases. ${ }^{9,12}$ Each hospital was equipped with its own pharmacy, library, lecture halls, mosque and occasionally a chapel for Christian patients. Musicians were employed to comfort and cheer patients via music therapy.

Upon admission, the patient's clothes and money were placed into trust. The patients received clean clothes and were freely given medication and food under physician supervision until they were cured. Upon discharge, the patient's possessions were returned to them and they were sent with clean clothes and a grant of money to compensate them for lost wages and aid them in establishing a new livelihood.

Bimaristans also pioneered the development of written medical records. ${ }^{8,14}$ It was the students' responsibility to keep records of the patients and their medical treatment. These admirably detailed records were compiled, edited by clinicians, and formatted in a way that became known as 'treatments based on repeated experience.'

\section{LICENSING OF PHYSICIANS}

Another lasting advancement made during this time period was that of physician licensure. In 931 AD Caliph AlMuqtadir learned that a patient had died in Baghdad as a result of a physician's error. Consequently, he ordered Sinan ibn Thabit to examine all those who practiced the art of healing. Of the 860 medical practitioners he examined, 160 failed. ${ }^{8}$ From that time on, licensing examinations were required and administered in various places. Licensing boards were set up under a government official called Muhtasib, or inspector general. The chief physician gave 
oral and practical examinations, and if the young physician was successful, the Muhtasib administered the Hippocratic Oath and issued a license to practice medicine. ${ }^{8}$

\section{MEDICAL SCHOOLS}

Many bimaristans also contained medical schools for resident and student education. The ablest physicianssuch as Al-Razi (Rhazes), Ibn Sina (Avicenna) and Ibn Zuhr (Avenzoar) - were both hospital directors and deans of medical schools. ${ }^{8}$ Only Jundi-Shapur and Baghdad had separate schools for teaching the basic sciences. ${ }^{8}$ Otherwise, these were taught at the same facility as the clinical instruction. Basic science preparation consisted of lessons from private tutors, self-study and lectures. Anatomy was taught through lectures, illustrations and ape dissections. ${ }^{8}$ Students also studied medicinal herbs and pharmacognosia. The clinical training was accomplished by assigning small student groups to experienced instructors for ward rounds, discussions, lectures and reviews. ${ }^{14}$ Therapeutics and pathology were taught early on. After a period of ward instruction, students were assigned to outpatient areas. The keeping of detailed medical records for every patient was the responsibility of the students, as detailed above. ${ }^{14}$

\section{LIBRARIES}

Extensive libraries were attached to the hospitals, containing the most up-to-date books. In $872 \mathrm{AD}$, Tulum Hospital in Cairo had 100000 books. Mustansiriyya University in Baghdad had 80000 volumes, Cordova library had 600000 volumes, Cairo had 2000000 volumes and Tripoli had 3000000 volumes. ${ }^{8}$ To grant some perspective, in the 14th century Europe's largest library, at the University of Paris, consisted of a mere 400 volumes. The library at Tripoli was 7500 times the size of that in Paris!

\section{CONCLUSION}

Building upon the inspiration afforded by the bimaristan at Jundi-Shapur, near- and middle-easterners transformed hospitals into institutionalized establishments for patient care, medical education and training. The complex structure and hierarchy of these hospitals, advent of medical records, physician licensure, government oversight and universal access to care set the example upon which later hospitals were modelled. Much of the history of early western medicine was denigrated by the destruction of ancient libraries and the ethnic purging of near- and middleeasterners from western medical history texts. It is purely cultural nepotism to assert that western hospitals developed independently of their near-eastern predecessors, when Spain and Portugal (part of the Islamic empire for over 700 years) were riddled with bimaristans. Cordova alone had fifty major hospitals and the Granada bimaristan served as the model for the Hospital Real in Santiago di Compostela and later Granada hospital, commissioned by Ferdinand and Isabella. . $^{32}$ Physicians fleeing Spain moved on to establish academic medical centres in other European cities such as Salerno. ${ }^{3}$ Additionally, upon returning from a crusade, the Knights of St John were called 'Hospitallers' due to the hospitals they constructed based upon the Arabic model founded by Saladin. ${ }^{6,9}$ Between the Andalusian hospitals, those in the lands of the Crusades and the bimaristans, where westerners were treated along trade routs and during travel expeditions, westerners had extensive interactions with the bimaristans that were nearly 1000 years the predecessors of their western counterparts. They treated inpatients and had outpatient clinics. They travelled to prisons and treated the mentally ill. ${ }^{9}$ They cared for all who sought treatment and turned none away. Medical schools and resident physician training blossomed. Physicians kept written medical records, saw to standardized physician licensure, and amassed libraries 7500 times the size of the largest 14th century European library. Our near- and middle-eastern colleagues were true visionaries, and the founders of the academic medical centre.

Competing interests None disclosed.

\section{REFERENCES}

1 Nagamia H. Islamic medicine history and current practice. Journal for the International Society for the History of Islamic Medicine 2003;2:19-30

2 Allan N. Hospice to hospital in the Near East: an instance of continuity and change in late antiquity. Bull Hist Med 1990;64:446-62

3 Sa'di LM. Glimpses into the history of Arabic medicine. Bull Med Lib Assoc 1958;46:206-18

4 Dols MW. The origins of the Islamic hospital: myth and reality. Bull Hist Med 1987;61:367-90

5 Bayon HP. Arabic philosopher-physicians and Christian doctors of medicine; a contribution to the knowledge of the origin of the Moslem revival of science and the derivation of the medical profession. Proc $R$ Soc Med 1952;45:310-4

6 Brewer H. Historical perspectives on health. Early Arabic medicine. $J R$ Soc Health 2004; 124:184-7

7 Savage-Smith E. Islamic Culture and the Medical Arts: an exhibit at the National Library of Medicine. Bethesda, Maryland, 1994. Available at http: / /www.nlm.nih.gov/exhibition/islamic_medical/islamic_00.html

8 Syed IB. Islamic Medicine: 1000 years ahead of its times. Journal for the International Society for the History of Islamic Medicine 2002;2:2-9

9 Stone C, Lunde P. Early Islamic hospitals: in the hospital bazaar. Health Soc Serv J 1981;91:1548-51

10 Herrmann ET. Early Arabian Medicine. Bull Med Lib Assoc $1936 ; 25: 113-7$

11 Kump WL. Historic hospitals. Financing the Maristan of Qalaun. Minn Med 1974;57:464

12 Galton DJ. Destruction of a hospital. J Roy Soc Med 1997;90:406-8

13 Kump WL.Historic hospitals. Arab hospital architecture. Minn Med 1972;55:1040

14 Kump WL. Historic hospitals. The Nuri Hospital, Damascus. Minn Med 1972;55:710

15 Kump WL. Historic Hospitals: The bimaristan at Jundi Shapur. Minn Med 1972;55:14 